\title{
A backpacker habitus: the body and dress, embodiment and the self
}

AQ1 Michael O'Regan

\section{ABSTRACT}

As all cultures 'dress' the body through clothing, tattooing and other forms of body adornment such as cosmetics, dress offers a useful lens through which to explore the ways in which identities are constituted in modern leisure and tourism cultures. An analysis of the dress and embodied subjectivity of western backpackers in Nepal finds that dress is constitutive of selfidentity and the ways backpackers imagine themselves. This study argues that dress remains an important aspect of a secondary socialization that, in an evolving process, leads to specific (western) backpacker habitus. The use of Pierre Bourdieu as a theoretical resource unravels the relationship between body and dress, embodiment and the self and shows how dress embellishes the body by adding an array of meanings within backpacking culture.

\section{Introduction}

Our awareness of large-scale movements of people over social and geographic space has increased due to the speed of communication and the mobility of images and ideas, with mobile figurations and their practices filling our Smartphone and television screens, literature, imagination and discussions. From the itinerant-worker, globetrotter, transnational criminal, international student, terrorist, second home owner, migrant, business person, sports star and refugee to the soldier, it seems larger numbers of people are moving or are being forced to move. One particular form of tourism characterized by extensive spatial mobility is backpacking, wherein budget-independent travellers characterized by time and space flexible travel for up to one year or more on routes that span the globe (Berdichevsky, Poria, and Uriely 2013). Their social world of relations and movement remains difficult to articulate and challenges researchers to 'keep up' with the complexity of the everyday experiences that take shape and gain bodily expression in their world. By moving beyond a mere description of backpacker dress, this study explores the relationship between the body and dress, and how dress is an important element in moving socially, temporally and spatially the 'right' way as a backpacker. 


\section{Literature review}

The global spread of backpacking has been critically explored over the past 30 years with various overlapping definitions acknowledging, identifying and demarcating backpackers as a distinct cultural formation in ethnographic studies (Shaffer 2004; Sørensen 2003). They are described as budget-minded, independent travellers breaking routine with home to construct and sustain their identities as they move from geographic to geographic location with a high rate of change in their local environment. Backpacking as we know it today is a product of history and is infused by countercultural discourses. It continues to draw heavily upon a stock of knowledge which is culturally, socially and historically conditioned from a specific period of societal flux in the 1960s and 1970s.

The western countercultural period between 1964 and 1972 (Suri 2009) saw the breaking down of systems of relationships (educational, political and social), increasing mobility, changing social structures, innovative technologies and new media. Countercultural exploration of alternative forms of social and spatial organization by the so-called hippies provided access to an alternative way of life. Their spatial, communal and constructive imagination sustained a 'move east' where hippies, anti-war activities, freaks, heads and beats from North America and Western Europe traversed Europe to India and beyond. An organized drift (1965-1975) evolved after the emergence of the counterculture in the United States, and continued for a short period after its end. It brought dispersed people who wished to demonstrate their countercultural belonging together on a journey and created a network of places and material infrastructure that were propagated visually through niche media and maps, and linguistically through myths and stories (MacLean 2006; Stephens 1998; Tomory 1996). While two centuries of leisure travel taught westerners how to be tourists (Stonza 2001), these emerging landscapes were the product of alternative ideas and ideologies. The journey east came to be seen 'as providing the necessary challenges and opportunities to expand oneself in areas valued by adventurous youth: independence, adaptability, resourcefulness, open-mindedness to name but a few' (Vogt 1976, 27). It made it possible to throw off certain routines, formal lifestyles and selves, so as to engage the world on alternative terms. As the counterculturalists who drifted east affirmed and reinforced what they thought they knew about the world, new material and irregular routes spread to Greece, Morocco and even China (Farber and Bailey 2001).

By the late 1960s, the drift east itself evolved into an organized field of social practices. More than any other route, the hippie trail to India and Nepal captured the imagination of western youth as stories, buses, drugs, objects, money and ideas all travelled 'the road east' (Raj 1976, 42). As tens of thousands of travellers moved, with international visitors in Nepal rising from 12,500 in 1966 to 90,000 in 1974 (Tomory 1996), they came to be labelled as 'drifters' (Cohen 1973). Their journeys engendered a new subjectivity not inextricably linked to existing economic and social systems and was often performed as an alternative to middle-class conformity and the traditions of a petit-bourgeois middleclass habitus. As individuals populated the road east in greater intensity, their movement became mapped and visible and the landscapes became haunted and tainted by their representations in the mainstream media. (Cohen 1973). Their dress, posture and language identified them, and the drifter became a symbol of moral breakdown and the potential disorder of mobility. The governments of Argentina, Greece, Italy, Singapore, Thailand and 
Yugoslavia asked (and often forced) young travellers to cut their hair and shave before entering the country (Neville 1970; Nikolakakis 2015; Wheeler and Wheeler 2007). French immigration officials were instructed to refuse admission to persons whose 'unkempt clothes, shaggy hair and evident uncleanliness might be thought to offer an undesirable spectacle' (Neville 1970, 163). Turner and Ash (1976) note that officials around the globe considered adopting aesthetic criterion as part of entry requirements. The governments of Crete, Israel, Thailand, Morocco, Laos, Pakistan, Italy, Germany, Spain, Tanzania, Turkey, the United Kingdom, Taiwan and France imposed entry restrictions and stricter laws for drug possession, drug smuggling, public nudity, beach sex and hitchhiking (Sharma 2000).

Even though national governments sought to close down drifting, the imaginative geographies of these travellers remained alive by way of alternative guidebooks, films, images and books. Charged with cultural, social and historical meaning, individuals (re)acquired a consuming passion for new and recycled countercultural styles in the mid-1980s. While the term backpacker was around since the late 1970s, it came to be reused in the 1990s to describe those individuals who were again actualizing discourses attached to the western counterculture of the 1960 s by once again making statements about themselves through long-term and long-distance budget travel. The popularity of backpacking rose in tandem with a burst of globalization that produced flows of individuals who could afford to make their way within a world that remained seductive and bound up with geographic imaginaries of places and encounters. Backpacking remains a (temporary) address that offers a new individualized identity, with Said $(2001,404)$ noting that:

[t] he image of traveler [backpacker] depends not on power, but on motion, on a willingness to go into different worlds, use different idioms, and understand a variety of disguises, masks, and rhetorics. Travelers must suspend the claim of customary routine in order to live in new rhythms and rituals.

These rhythms are often confusing as individuals insert themselves into a complex social and spatial environment which demands a great deal of personal and embodied involvement in everyday life with others, as well as bodily involvement in the fullest social and historical sense.

Between 2005 and 2010 (O'Regan 2010), I sought to engage in a curious, open-ended, engaged exploration of backpacking and how its recognizable coherence is reproduced by way of an inductive approach called methodological bricolage (O'Regan 2015). I drew from ideas, notes, observations, interviews, photos, practices, literature, blog entries, stories and conversations with backpackers whilst backpacking for a one-year period in South America and Asia. As I experienced belonging, the mundane, friendship, happiness, joy, crisis, synchronicity, discomfort, friction, loneliness, movement, disorientation, stillness and unplanned encounters with self-identified backpackers, I was able to move into a new, more complex, domain of knowledge production and challenge assumptions, established values and claims to truth. I begin to decipher and connect isolated pieces with other apparently isolated pieces of data, connect parts to the whole and stitch pieces together in a pragmatic and self-reflective way so as to contextualize and conceptualize different aspects of backpacking and work outwards towards the expansion of knowledge. 
After employing multiple strategies and often competing theories of tourism such as anthropological theories of globalization (Appadurai 1990), actor-network theory (Callon 1999), the theory of collective action (Olson 1965), Giddens' ability theory of practice (Giddens 1984), worldmaking (Goodman 1978), serious leisure (Stebbins 1982), leisure involvement (Havitz and Dimanche 1997), the travel career trajectory (Pearce and Lee 2005), De Certeau's (1988) theory of everyday practices, the theory of cosmopolitanization (Beck 2000), social world theory (Unruh 1980) and Garfinkel and Wieder's (1992) theory of practice, my conversation with Pierre Bourdieu began. The Bourdieusian concepts of habitus, capital and field acted as a form of glue and allowed me to investigate the conscious (and unconscious) beliefs, norms, forces, practices and embodied acts that set the pace and pattern of interrelations amongst backpackers and constitutes their sense of the world. As backpackers are often unaware of many of the values that bind them together or cannot explicitly verbalize those values, Bourdieusian concepts explain the human drama and contradictions within a complex, interconnected world.

\section{The backpacker habitus}

Most people will change their habitus more than once in the course of a single lifetime and may end up transiting across several habituses (Waterson 2005), each with a specific orientation to, or way of being in the world (Sweetman 2003). Many backpackers I interacted with during my research travelled after a temporary disengagement or a full blown 'biographical rupture' (Fillieule 2010), such as a departure from a life course (job changes and redundancy) or a breakdown of other systems of relationships (educational, religious, political and social). This suggests that backpacking can still be considered disjunctive, as informants described their decision to travel as a means to gain temporal, social and spatial distance from previous roles and life courses. When sufficient desire, motivation, involvement and action is linked to movement beyond the familiar, such movement over landscapes of mobility may come to constitute a 'field' from where a secondary socialization and a specific habitus may take form. Rather than a primary socialization phase when adolescents internalize dispositions with interacting with significant others such as parents and peers, a secondary socialization may occur in a social world that provides new influences on a person's modes of thinking and acting (Berger and Luckmann 1967). Direct (and mediated, through guidebooks, etc.) experiences promote this secondary socialization as they provide a frame of reference for interested and motivated individuals.

A western backpacker habitus provides its carrier with a sense of one's (and other's) place and ensures backpackers become disposed to act in some ways more than others as they learn (consciously and unconsciously) new skills, competencies and (sub-cultural) knowledge. A habitus is a set of dispositions and is internalized as 'practical intuition' and implies a bodily, reflexive 'know how' (Bourdieu and Wacquant 1992). Bourdieu $(2000,143)$ argues that, once carried, individuals are 'caught up in it, bound up with it... like a garment ... or a familiar habitat ... at home in the world because the world is also in him [sic], in the form of habitus,. What is produced through the backpacker habitus in terms of practices and bodily performances is not merely a passive replica of an ideology, rules or a guidebook, but rather a manifestation of a generative set of dispositions individually and collectively performed, socially situated and oriented towards the accumulation of (sub)cultural capital. 


\section{The backpacker habitus and the body}

With its own particular norms, logic and stakes, a backpacker's social world is encapsulated within the temporal, social and spatial context of a field and is made coherent by way of (sub)cultural capital (Thornton 1995) which comes in the form of embodied competencies or dispositions which carry cultural value (Crossley 2001). While cultural capital exists in three forms (embodied, objectified and institutionalized) (Bourdieu 1996), backpackers, through conflict and competition, largely seek to attain embodied and objectified capital. The set of dispositions backpackers acquire depend on 'their particular endowment in capital' (Wacquant 1998, 221) with capital accumulation, embodiment and communication conferring status on its owner, as well as initiating and sustaining an identity and group boundaries (Lamont and Molnár 2001). A by-product of individual activity and labour, the volume and type of capital also establishes a hierarchy through which adherence to the logic of the field is policed (Peillon 1998), given it indicates whether a person has various dispositions and can demonstrate a legitimate knowledge of the field. Bourdieu's concept of habitus demonstrates the ways in which the social world exists in the body, with Bourdieu $(1977,214)$ noting how the habitus 'designates a way of being, a habitual state (especially of the body) and, in particular, a predisposition, tendency, propensity or inclination'.

When manifested in dress, habitus enables us to explore how individuals orientate to particular circumstances and 'recognizes the structuring influences of the social world on the one hand, and the agency of individuals who make choices as to what to wear on the other' (Entwistle 2000a, 37).

(Sub)cultural capital therefore is linked to the body and presupposes embodiment, given that as well as regulating access to the social world, individuals need to 'learn bodily' (Bourdieu 2000, 141). Individuals must become bodily 'exposed to the world', be 'capable of being conditioned by the world' (Bourdieu 2000, 134) as they learn to accommodate the shifting bodily requirements imposed by their own transition. This body work (Gimlin 2007) is both an individual creation (physically and phenomenologically), and a cultural product from the social world, given that the social world imposes particular ways of being on the body (Goffman 1971). Even before the journey, the backpacker body is made fit-for-purpose, with vaccinations, travel insurance and first-aid kits incorporated, performed and rendered through the body as embodied expressions of backpacker consciousness.

During the 1970s, the hippies differentiated themselves from mainstream culture through their bodily gestures, hair, dress, posture and decorum (Farrell 1997), with Teas ([1988] 1974) noting that their bodily desires were constitutive of their self-identity and the ways they imagined themselves. They created a carefully crafted look with secondhand clothes, long hair, shawls and beads to highlight their superior awareness (Mills 1973). Teas ([1988] 1974) argues that the clothes that drifters wore were those of the peasant but fashionable and the refusal to wear wristwatches was symbolic of the routines and lives they sought to leave behind. Neville $(1970,10)$ describes how the drifters wore 'Arabian headdresses, Indian sandals and beads, Nepalese earrings, a Thai Buddhist shoulder bag, an Afghanistan embroidered leather coat and blue jeans' while Zurick $(1995,66)$ notes that drifters in 1970s Kabul shopped for shepherds' embroidered 
cloth of the desert, with travellers quickly trading 'their dusty Western clothing for desert costumes at the second-hand clothes dealers that were so prolific in the city'.

By freeing themselves from western clothes, foods, religions, styles and even passports (Stephens 1998), drifters symbolically shrugged off their societies (Mills 1973). Zurick $(1995,66)$ explains that by adopting native dress, travellers 'demonstrated to other Westerners that the passage from their own world to that of the "other" had indeed been achieved, a passage that deserved recognition and certainly a new look'. They embodied the world (the pathways, routes and roads) they inhabited, including the journey's edginess, roughness and risk. This meant hepatitis, tattoos, piercings, beards, long hair and malnourishment were prevalent (Neville 1970), as bodies were made visible and expressive (Crouch 2005). By disciplining the body, drifters ensured their body image was consistent with the social identity they wanted to convey (Johnson 2008). Tomory described those heading out east and those returning as 'On one side of the road, the healthy, with their money, passports and jeans; on the other, the skinny, the strung out, the sick, the poor ... But they were smiling' (1996, 50-51).

Bourdieu argues that bodies reveal 'the deepest dispositions of the habitus' $(1984,190)$ as bodily modifications result from being possessed by a world. The body is a symbol of status, a system of social markings and a site of distinction (Thorpe 2004), with dress serving 'as a sign that the individual belongs to a certain group, but simultaneously differentiates the same individual from all others: it includes and excludes' (Barnes and Eicher $1993,1)$. While there have been a small number of descriptive studies of backpacker dress (Hottola 2008; Welk 2004), this paper incorporates the body (Entwistle 2000b, 2014) as well as draws on Bourdieusian concepts to connect theories of the body and theories of fashion and dress.

\section{Methodology}

Past ethnographic approaches have made backpacking familiar, with recent rich studies highlighting the strong emotions determined by the everyday practices of backpacker consumption (Falconer 2013) and backpacking in China (Luo, Huang, and Brown 2015). However, the phenomenon of backpacking is only partially amenable to conventional ethnographic studies given the specific situational nature of many studies. Methodological gaps often strip the backpacking experience down to bare budget-minded travel, and ignore elements of creativity, colour, character and voice. As I remain invested in, and moved by this type and form of travel (even after my initial academic study), I ensure different voices continue to be heard, new encounters acknowledged and facets of existence illuminated. During August and September 2014, I travelled to Nepal for one month. I spent 15 days in the backpacker enclave of Thamal in Kathmandu and 15 days $200 \mathrm{~km}$ west of the capital at Lakeside in the city of Pokhara. Although much of the infrastructure associated with drifting ceased to substantially exist in other parts of the world, budget travel never disappeared from Nepal and still tends to draw experienced backpackers, along with trekkers and organized tour groups.

The backpacker enclaves of Thamal and Pokhara are spaces where discourses and practices come together to make backpacking a very visible reality. Nepal attracted drifters in the 1960s and 1970s and remains a favoured destination for many reasons (Hinduism, Buddhism, yoga, meditation, mountains, along with low costs of living and easy access 
to drugs). Freak Street (named after the freaks that travelled to Jhochhen Street in the 1960s) remains, and is where the infamous Eden (drifter) Hotel is still situated. The liberal visa-on-arrival policy of Nepal means every foreign national (with the exception of eleven nations) can obtain a multi-entry tourist visa of up to 90 days. My stays in key staging spaces (places and events) in both cities allowed me to listen, learn and interact with numerous backpackers. As I was not a novice to backpacking, the routes they travelled and their spaces of consumption, I was able to gain trust and establish rapport. I also utilized a local research assistant in both Thamal and Pokhara to take photographs and transcribe interviews.

While 15 informants (Table 1) were interviewed through English in various locations in Kathmandu and Pokhara for between 15 and 40 minutes, only 5 of those informants agreed for the interviews to be recorded and allow pictures of their dress style to be taken. The informants who allowed recording and photos allowed questioning of a greater depth over longer periods of time than those informants who did not (field notes were written up after those encounters). There was a point of diminishing return in the sample, with Guest, Bunce, and Johnson (2006) noting that 12 interviews of a homogenous group may lead to saturation. After transcribing the interviews, the data were analysed using content analysis. As main themes emerged, key quotes were selected together so as to achieve an accurate data analysis process.

As a strategy to add richness and colour to this research and to enable the reader to draw their own conclusions from participants' words, verbatim quotations from the five

Table 1. Informants.

\begin{tabular}{|c|c|c|c|c|}
\hline Informants & Gender (age) & & $\begin{array}{l}\text { Travel } \\
\text { length }\end{array}$ & Observations \\
\hline Nico & $\mathrm{Ma}$ & & 6 months & $\begin{array}{l}\text { Cotton Ali Baba trousers, green cotton top, Tibetan } \\
\text { necklaces, earrings, braided hair, Nepali hat, beard }\end{array}$ \\
\hline John & & & $\begin{array}{l}\text { Open } \\
\text { ended }\end{array}$ & Scandals, shawl, Buddhist bracelet, blue sweater, beard \\
\hline Rachel & Fem & White, British & $\begin{array}{l}\text { Open } \\
\text { ended }\end{array}$ & Nepalese Kurta, cardigan, Cambodian scarf \\
\hline Adrian & & $\begin{array}{l}\text { White, } \\
\text { American }\end{array}$ & $\begin{array}{l}\text { Open } \\
\text { ended }\end{array}$ & $\begin{array}{l}\text { Hemp vest, lungi, Thai fisherman's pants, Sherpa wool hat, } \\
\text { beard, long hair }\end{array}$ \\
\hline Sandra & Female (20s) & White, German & $\begin{array}{l}\text { Open } \\
\text { ended }\end{array}$ & $\begin{array}{l}\text { Nepalese hand-woven shawl Malaysian aboriginal bracelet, } \\
\text { Nepalese woollen socks and sandals }\end{array}$ \\
\hline Int6 & Male (20s) & White, British & $\begin{array}{l}\text { Open } \\
\text { ended }\end{array}$ & Black T-Shirt, Black Thai fisherman's pants and sandals \\
\hline Int7 & Male (20s) & White, German & 4 months & Shirtless, with cotton pants (in guest house) \\
\hline Int8 & Male (40s) & $\begin{array}{l}\text { White } \\
\text { (unknown) }\end{array}$ & $\begin{array}{l}\text { Open } \\
\text { ended }\end{array}$ & Barefoot, singlet and earrings \\
\hline Int9 & Female (30s) & White, French & One year & $\begin{array}{l}\text { Multi-coloured baggy harem trousers, cotton top and } \\
\text { sandals }\end{array}$ \\
\hline Int10 & Female (30s) & $\begin{array}{l}\text { White, } \\
\text { American }\end{array}$ & Unknown & $\begin{array}{l}\text { Indian style Kurta, colourful cross body bag, shawl and } \\
\text { sandals }\end{array}$ \\
\hline Int11 & Male (20s) & White, Irish & 2 months & No observations during nighttime interview \\
\hline Int12 & Female (40s) & White, German & $\begin{array}{l}\text { Open } \\
\text { ended }\end{array}$ & Indian (Jaipuri) skirt, colourful backpack. A ruana style shawl \\
\hline Int13 & $\begin{array}{l}\text { Male } \\
\quad \text { (unknown) }\end{array}$ & White, British & $\begin{array}{l}3-6 \\
\text { months }\end{array}$ & $\begin{array}{l}\text { Hippie style fleece, cotton pants, sandals, beard and long } \\
\text { hair }\end{array}$ \\
\hline Int14 & Male (30s) & $\begin{array}{l}\text { (Unknown), } \\
\text { Dutch }\end{array}$ & Unknown & Indonesian Batik pants and Thai Muay Thai style T-shirt \\
\hline $\operatorname{lnt} 15$ & Male (20s) & $\begin{array}{l}\text { White, } \\
\text { Canadian }\end{array}$ & $\begin{array}{l}6-8 \\
\text { months }\end{array}$ & Cotton shirt, Thai style pants and generic backpack \\
\hline
\end{tabular}


recorded informants are utilized. The interview scripts were de-identified and edited according to standards for using verbatim quotations in reporting qualitative research (Corden and Sainsbury 2006). The choice to draw only on the five transcripts for quotes acknowledges the role of the researcher(s) in the process of knowledge co-construction. Given my ontological position and my epistemological approach could be described as 'constructivist', but informed by participatory and interpretative paradigms, I sought to best exploit the richness and depth of the transcript data. The selected quotes from the five recorded informants consist of enough cases to examine the convergences (and divergences) found within all 15 informants.

\section{Findings}

\section{Dress and identity}

Backpackers produce a new self by crafting new sets of feelings and dispositions by working on the body, with the informants feeling a social and (and even moral imperative) to perform their identity through new gestures, postures, spoken words and dress. Developing these dispositions is an entire performance and constitutes a new presentation of self. Bodily and physical transformation works to 'glue' their developing identities, with Wilson (1985) noting the way in a world where identities are uncertain, dress may stabilize our individual identity. All informants spoke of throwing away, sending home, gifting and swapping their clothes and other objects from their home countries, with Turner and Ash (1976) suggesting the tourists' sensuality and aesthetic sense are not as restricted as they are in their home country. One participant, Nico (Interview, Pokhara, 2014), threw away all his western clothes in India while, another participant, Rachel (Interview, Kathmandu, 2014), had disposed of her western clothes in Thailand. Adrian (Interview, Kathmandu, 2014) noted how he had first visited India 10 years previously, and was 'wearing the clothes that were available to me in life ... western clothes, t-shirts, pants, shorts', but soon abandoned them. Only Sandra (Interview, Pokhara, 2014) had worn similar hippie style clothing at home in a large urban centre in Germany where she considered them accepted. Adrian expressed a desire to wear alternative clothes at home in America after his initial trip to India. However, after seeking to wear a sarong, Adrian (Interview, Kathmandu, 2014) was 'accused' of being homosexual and had to revert to conventional clothing. However, now in Nepal, he could wear what he felt were natural items of clothing and abandon his T-shirts because they were unnatural.

All the informants noted their struggle for individual mastery through active engagement with the world they were seeking to belong to and to articulate that belonging at early stages of their travels. As a way of fashioning the self and fitting in, dress is a 'biographic process of changing the inner person to fit new outer garments' (Colchester 2003, 15), given it is a visible form of one's intentions. Adrian (Interview, Kathmandu, 2014) noted that when he got to Thailand he had purchased fisherman pants, and noted that 'a lot of the clothes I was raised wearing were actually uncomfortable', adding that 'if you change the way you look, it changes the way you feel about yourself', Adrian (Interview, Kathmandu, 2014) went on to say that: 
it out. Sometimes, we usually have a good time with it. Its kind [of], like, playful, put on a different mask, and be like a different person. It frees us up from something back home, all of our troubles and helps us remember that [a] vacation may be that life changing exposure to an alternative culture.

All 15 informants felt the clothes purchased in South Asia were well made, natural and airy. All the interviewees valued casual styles and comfort. Rachel (Interview, Kathmandu, 2014) noted that all the clothes she brought from England were too hot, and the fabric was too thick, while Adrian noted that clothes in Nepal (especially those he considered made by Tibetans) were non-synthetic, tougher, stronger and more durable. Nico (Interview, Pokhara, 2014) bought clothes that the locals wore because they 'know the weather', while Adrian (Interview, Kathmandu, 2014) felt his locally bought clothes were good for the mountains, since they emerged 'from a culture that understands mountain life'. For Adrian, wearing ethnic Tibetan clothes, including the traditional vest of a Tibetan monk and a monk's shoulder bag was a moral imperative, given his support for an independent Tibet. He believed he was representing Tibet through his dress and that this supported 'peaceful people that are teaching the world about peace'.

Informants made it clear that their dress style and visible bodily adornments cost them time rather than money. Such time 'must be invested personally by the investor' (Bourdieu $1986,224)$, its acquisition meaning 'work on oneself' (self-improvement), an effort that presupposes a personal cost, energy and sacrifice. This reflexivity becomes mediated through the habitus, so as to appropriate scarce capital that can be used to present a desirable image, even if such accumulation is risky and demanding. Many of the formally interviewed participants were not confident in their appearance and bodily presentations early in their travels, with Adrian (Interview, Kathmandu, 2014) noting it was sometimes difficult:

Many people think I am trying to look like one thing or another. But actually I am just being myself. I have to deal with peoples' judgements. They all look at me, and think I am weird and a freak because I don't dress like a normal person, or a normal anybody. I have to not care what I look like, and laugh at myself in order to get away with wearing the clothes that I like.

\section{Travel sentiments}

As well as having functional use, the majority of informants felt their dress had deeper personal resonances and were connected with particular places and encounters. Sandra had received a bracelet from a member of the Orang Asli (aboriginal people) in Malaysia, and had become very close to it given the connections she felt with those people. For John, a trip to a local Hindu temple, and getting a bracelet from a sadhu, was an intensely corporeal experience. As soon he walked into the temple he got a bindiya on his forehead and the sadhu 'spilled flowers on me, holy water, he tied this [cotton bracelet] around my hand and then asked for one thousand rupees' (John, Interview, Pokhara, 2014). John also attended Shivaratri, a Hindu festival. He noted there was nothing more memorable than interacting bodily with naked smoking babas (a sadhu is usually referred to as Baba by common people), and having a symbolic reminder by way of a holy bracelet, which he said he would wear every day until it fell off. Adrian also noted that he received most items of his dress as part of a non-monetary exchange or as gifts and were worn until 
they wore out. He recalled a friendship with a Baba in India, wherein they exchanged clothing upon parting. Of the lungi (sarong) he had received:

I loved it so much because our friendship was so fun in the Himalayas. We were best friends, like brothers, and when we left, that piece of clothing was my way of being connected with him and the mountains of India. I wore this for a long time and it was my favorite piece of clothing. (Adrian, Interview, Kathmandu, 2014)

The informants believed their clothes were quite unique and scarce. However, this scarcity was not based on high prices, with clothes often gifted or purchased at the lowest prices possible. Bargaining was based on their belief in their sense-derived knowledge, competencies and skill. Nico (Interview, Pokhara, 2014), for example, had sought a scarf, but was quoted 500 [Nepalese Rupee] and 'had to fight for her for the price and I got her down to $200^{\prime}$. Adrian argued most of his clothes were gifted to him, and each item was handmade and unique. Figure 1 shows Adrian, and his dress style, who indicated knowing what is appropriate dress, as well as interpreting and understanding backpacker dress style, and therefore confirming his (sub)cultural/capital.

\section{Making connections}

As raw material, Entwistle (2014) argues that dress is an inter-subjective and social phenomenon that links individual identity and social belonging, while Davis $(1992,25)$ argues that dress frames an embodied self and serves as 'a kind of visual metaphor for identity'. The informants utilized dress to scan others, and facilitate their reading by others. Adrian (Interview, Kathmandu, 2014) feels that his dress communicates that he

Figure 1. Adrian and his dress style. 
is a world traveller and not totally American, noting how his dress 'shows I am a little bit distinguished from the mainstream and I am an alternative type of person', John (Interview, Pokhara, 2014) mentioned that:

people will always check each other out no matter where in the world they are and give a scan. 'Where can I fit you?' You see the Thai fisherman's pants here a lot so you know those people have been to Thailand. Or Canadians always wear a flag on their backpacks.

Nico (Interview, Kathmandu, 2014) noted that 'you can kind of tell how long someone's been going or where they have been because you're like ... I recognize that, I saw that in this town or in this country', He went on to note that:

you could instantly tell the people who would come from India cause their clothing would always be quite complicated and you'd have scarves and layers and bracelets and necklaces, whereas someone who's come from say Vietnam, their stuff would be quite normal. It won't look that different. So you can tell where people have come from and how long they've been there.

Dress transforms the body into something recognizable and meaningful to backpackers as they seek to connect with other validating bodies. Adrian (Interview, Kathmandu, 2014), for example, noted that 'If I see someone dressing a little more alternative or a little more unique, I think they might be on the same wavelength and a little more approachable.'

\section{Not passing for tourists or locals}

Dress was used as a means to classify respondents and others in terms of possessions, practices and performances, with all informants mentioning they did judge tourists and their dress. Rachel (Interview, Kathmandu, 2014) noted that 'I saw a girl wearing shorts and I thought "Oh! Why is she wearing shorts?" That's not what you should wear.' Rachel mentions that 'I try and wear what is respectful to the local community.' Nico (Interview, Pokhara, 2014) believed he could identify western tourists with generic clothes, and noted that 'if they are wearing stuff like cargo shorts, you know like a t-shirt that you recognize from a shop back home, and you instantly sort of assume something about them', Nico instead wore clothes 'that makes it look like you have been in the country for a while', He went onto note that:

If you look too western it automatically makes you look really touristy. And especially in a country like in India or in a really busy city like Kathmandu you don't want to stand out as the tourist because that makes you a bit of, not a target, but you know what I mean, it does make you seem a little bit, people will think you have more money.

Dress and bodily appearance according to informants can also be defensive, and a shield against tourists and touts. Adrian (Interview, Kathmandu, 2014) suggested that tourists who 'look' rich were reluctant to talk to a person dressed like him because 'they are really uptight ... and I try to get people that are uptight people to become freer just by the way I look', He believes that:

People putting on nice clothes are annoying. I am really annoyed by fake, superficial things. We are not going to have a deep conversation, probably, because they are too concerned about the way they look like and maybe they are going to look stupid if they think about the truth for a minute. 
The majority of informants understood they were not passing for locals, but had taken inspiration from various cultures. Nico (Interview, Pokhara, 2014) noted that his style (earrings and braided hair) is influenced by travel in India, as 'In India everyone is wearing everything, any part of your body they will adorn it.' John argued that 'I didn't want to blend in [with locals] ... . I wouldn't dress like a fake.' He also noted that 'when you get out of the backpacker zones and then suddenly you're in the local shopping zones and it's more normal, like clothes, regular jeans', Informants also recognized that local people did not wear what they were wearing. Rachel (Interview, Kathmandu, 2014) noted that 'I see most [local] people wearing jeans and Western stuff, jeans and jackets.' She continued by noting that 'I've seen them [backpackers] wearing the things that you see in shops, local people don't wear, but then travellers wear them like those baggy pants, like hippie clothes.' Adrian noted that his dress style gave out mixed messages given they were an assemblage of various cultural items. He noted that sometimes 'I kind of look like a Sadhu or Baba in India and people will treat me this way and sometimes treat me like a fake Baba, but they don't know me' (Adrian, Interview, Kathmandu, 2014).

The informants believed their dress style to be their own, even though they acknowledged their dress styles had tentative borrowings. They did not feel their style resembled a particular ethnic group or a uniform backpacker style. Nico (Interview, Pokhara, 2014), however, noted that 'I like travelling to new places and taking part of their culture and adapting it to my style.' This sentiment was also found in overland travellers in the 1970s by David Zurick. He noted that the distinctive fact about the wardrobes of the Asian travellers was that each was unique, and found that the 'cut of the clothing expressed not only the character of the person but also the nature of the travelers' inquiries into the new material world around them' (Zurick 1995, 66).

\section{Competition}

Backpackers distinguish themselves from each other given they are in a dynamic field of behaviour, where position-taking emerges as an individual 'commands access to the specific profits that are at stake in the field' (Bourdieu and Wacquant 1992, 98). As a form of embodied capital, bodily display and dress is an important performance. Dress, as much as vernacular use of language, posture and bodily deportment are convertible into symbolic and social capital. There is a breadth and depth in the backpacker habitus, where over time, it can become modified and reinforced by scarce and desirable capital. Backpackers, I found, are locked into relations of conflict and cooperation as they constantly renegotiate and rework their relations given these relationships are a source of identity, validation and even power. They are not merely searching for authenticity of the other, but searching for the authenticity of, and between, themselves. Those starting their journey incorporate a habitus that is strategic in the way it develops, is demonstrated, communicated and acted upon. The socialization process initially fastens the subject firmly to social structures (such as backpacker enclaves) and generates practices and performances that have a visible coherence. For John (Interview, Pokhara, 2014), those early in their journeys had a more generic look, which he described as 'loose pants and some dreads and some feathers in your hair. But that's like a generic backpacker',

Backpackers slowly gain gradual access to this world and the knowledge, skills and competencies embedded within it. They must pick up cues from others, before they too 
can become competent and knowledgeable as they learn the bodily: their routinized bodily performances over time engendering a more natural, confident and at ease projection. They use dress to differentiate themselves from other early stage backpackers. Nico (Interview, Pokhara, 2014) noted how he recognizes backpackers early in their trip. He said 'you can see travellers and they will still have a western looking scarf, and you know they haven't been here too long. Little things always tell you how long they have been going and where they have been'. As backpackers accumulate capital as a resource, the field gets under the skin. Each new encounter and experience provides new learning opportunities and reflexivity soon demands some re-interpretation of dress. The accumulation of (embodied) (sub)cultural capital enables individuals to act with a deeper knowledge and understanding of the field, its boundaries and their position in it. These latter stage backpackers often affirm their authentic self and their superior position to themselves and other backpackers by seeking to mobilize their competencies, knowledge and skills through dress, so as to struggle against labelling and ascribed discourses.

555 A tactical stance emerges after much travel experience and reflexivity with accumulated embodied capital manifesting itself as bodily naturalness and ease within the social world. Tactical backpackers perform backpacking to the point where it flows seamlessly from them, bodily and linguistically without any apparent effort or forethought. Both Adrian and Sandra, for example, feigned the position of the resistant, independent, autonomous, down-to-earth 'traveller' who can seek recourse in ambivalence, self-organization, self-reliance and uncertainty more than the other informants. Their bodily look and dress style incorporated items (from multiple locations, events and encounters) that cannot be easily replicated by those new to backpacking. Worn clothing, bracelets, amulets inscribed with prayer or magical prescriptions, beards, long hair and the ability to speak in the ver565 nacular (as regards religion, spirituality and drugs) communicated their struggles and victories. Both Sandra and Adrian thought their dress styles represented them, and both felt very at ease with their choices as they used intricate stories to draw out the individual histories of particular items of dress. Adrian (Interview, Kathmandu, 2014) believed his dress style helped others to feel freer, noting 'I think it inspires other people and it helps to free their mind a little.' Bell $(1976,19)$ argues that 'our clothes are too much a part of us for most of us to be entirely indifferent to their condition: it is as though the fabric were indeed a natural extension of the body, or even of the soul',

\section{Commodification}

The streets of Thamal and around Lakeside have been materially, discursively and symbolically altered by backpacking, as businesses seek to enable and reproduce a vibrant and profitable industry. Backpacker action has transformed space as its discourses, conventions and logic press into, and through, materialities, social spaces and systems. While the coherence amongst dress styles occurs to a large extent in the public realm of consumption and from self-fashioning by backpackers themselves, partial control has passed to autonomous economic forces that interact through a market ideology to produce landscapes encoded with clear cues and codes (Edensor 2001). The hundreds of retail clothing stores (Figure 2), selling backpacker style dress on the streets of Thamal and Pokhara, over-inscribe those areas with meaning and provide individuals with the opportunity to quickly and explicitly act to refashion their identities if they 


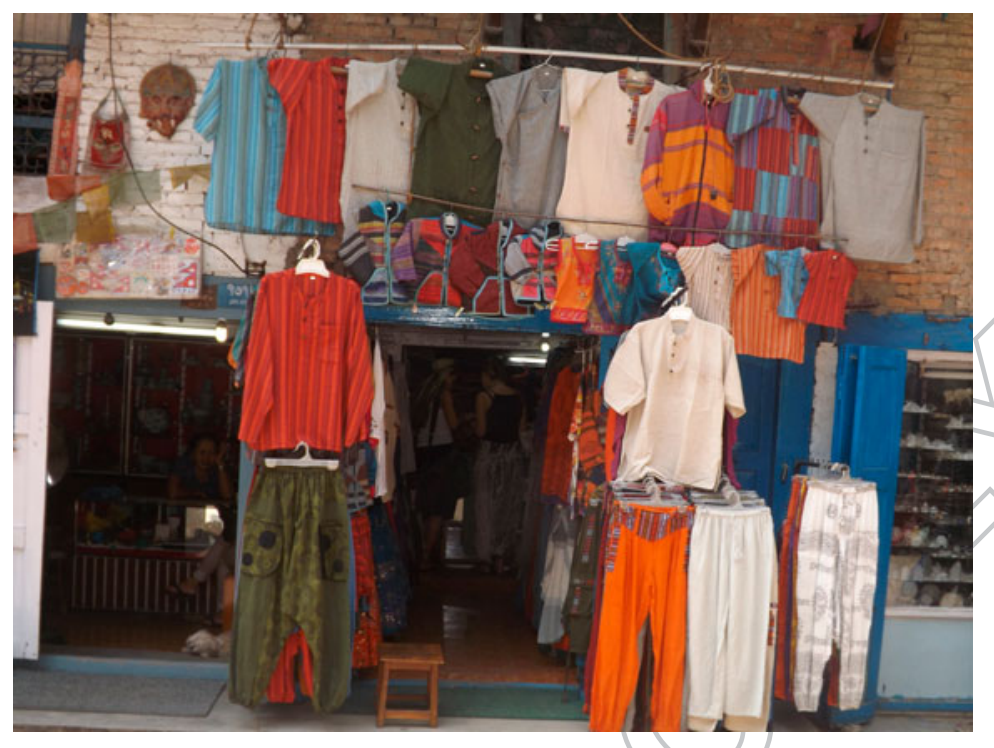

Figure 2. Shop front in Kathmandu with backpacker clothing.

wish. Figure 2 illustrates how individuals can quickly browse for a backpacker style as soon as they arrive to Nepal, with the stores offering immediate gratification for either a temporary or evolving identity (Joy et al. 2012). In many of these stores, I witnessed bargaining between backpackers and staff, with the stores themselves becoming a space in which the social field is felt. While far from a formalized retail and franchised industry, Nico (Interview, Pokhara, 2014) spoke of a backpacker, who had just arrived to India, but was not dressed for the weather. Nico recommended a scarf, but already knew what type of scarf he would buy, as 'everyone buys the same scarf as their first one',

\section{Discussion and conclusion}

Long-term travel is an indulgence, with the 15 backpackers formally interviewed marked with distinct criteria of colour and nationality. Their dress lacks acknowledgement of power relations, given their dress marks a distinct boundary between self and other, individual and society as well as between new and experienced backpackers (Entwistle 2000a, 2000b). Entrenched within formulated understandings, discourses and the hegemony of western values (Tesfahuney 1998), these embodied subjects are 'already marked by differences' (Ahmed 1998, 45). While the choice to go backpacking in any form is an expression of privilege, not all bodies move freely within their world, as 'some bodies must always negotiate the discursive structures that render [them] Other' (Puar 1994, 93). Bodies that lack embodied capital are subordinated because they lack the right bodily attributes. Asian backpackers (Teo and Leong 2006), for example, are often seen by western backpackers as out of place and locked into a position where agency becomes extremely hard to acquire. Bodies that do not conform and bodies that flout the conventions of backpacking culture risk being denied the affective dimension of forming relations with other backpackers. However, the different values of the increasing number of Asian backpackers 
(Paris, Ghazali, and Thinaranjeney 2015) may not reinforce existing western backpacker attitudes towards dress (Muzaini 2006).

As an situated bodily practice, dress is embedded within a backpacker's social world and is based on distributed (sub)cultural embodied capital that backpackers must accumulate. Taste and (embodied) capital in the consumption of dress is vital to be recognized as a competent, legitimate, credible and relevant member of this world. It is a visible commitment to the adoption of a sub-cultural identity and community, with tourists and other independent travellers not entering into the same kind of psychological, physical, emotional and corporeal communion with this world's logic and values. Informants, if travelling for sufficiently long enough, gradually disposed of their old dress style in an effort to transform their identity and experience a change of self. The desire to attach to a social world that links to others in patterns of passion, duty, survival, obligation, desire and commitment drives movement across countries and continents. Dress becomes a demonstration of belonging, of travel experiences, of confidence and authority as well as a useful vehicle to demonstrate distinction, capital and status. The body becomes a site of inscription, negotiation and distinction of social difference with the capacity to represent itself to others and to relate to others as distinct subjective identities in the world. The body's exposure and confrontation to the field is necessary in the production of subjectivities and the accumulation of capital, with Bourdieu $(1984,206)$ noting 'the selfassurance given by the certain knowledge of one's own value, especially that of one's body or speech, is in fact very closely linked to the position occupied in social space',

Corporeal transformation and dress works in tandem with the challenges, endurance and encounters of journeying as backpackers, with capital-accumulating strategies indicating an orientation to the world, given the dressed body is central to performing identity and interaction with other backpackers. Ultimately, dress helps to reproduce the social world, with Bourdieu (1984) acknowledging how social structures are reproduced at the level of bodily practices. As backpacker bodies are exposed to other backpackers, structures, systems and spaces, dress becomes a vital component in how backpacking is enacted, practiced, performed and communicated, and which ultimately feeds back into a continually reproduced and rejuvenated social world. As long as backpacking continues to draw geographically dispersed individuals laying claim to a collective spatial subjectivity which is radically different from the overregulated subjectivity in the home, school or work place, dress will still constitute an important symbolic marker of membership by transforming the body into something recognizable and meaningful. Dress remains central to transformation, revivification and insertion into a travelling philosophy that transforms backpackers from the inside out. Bourdieusian concepts draw out dress as a situated practice and backpacking as a lived experience which demands bodywork. Backpacker bodies are quite evidently still reflecting their journeys, with dress still acting as a medium to fashion the self and their social position. The western backpacker habitus, therefore, incorporates bodily dispositions, with dress constituting an important mode of meaning for backpackers and the values to which they subscribe.

\section{Disclosure statement}

No potential conflict of interest was reported by the author. 


\section{Notes on contributor}

Dr Michael O'Regan worked alongside the National Tourism Development Authority of Ireland before joining Gulliver after completing his Masters at the University of Limerick. He then joined Wicklow County Tourism as Marketing Executive before starting a Ph.D. programme at the School of Sport and Service Management, University of Brighton, United Kingdom which he completed in 2011. He is now a Senior Lecturer at Bournemouth University, United Kingdom.

\section{ORCID}

Michael O'Regan (D) http://orcid.org/0000-0001-8177-2739

\section{References}

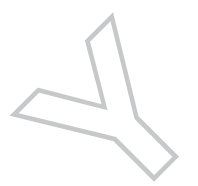

Ahmed, S. 1998. "Animated Borders: Skin, Colour and Tanning." In Vital Signs, edited by M. Shildrick and J. Price, 45-65. Edinburgh: Edinburgh University Press.

Appadurai, A. 1990. "Disjuncture and Difference in the Global Cultural Economy." Theory, Culture and Society 7 (2): 295-310. doi:10.1177/026327690007002017.

Barnes, R., and J. B. Eicher, eds. 1993. Dress and Gender. Making and Meaning in Cultural Contexts. Oxford: Berg.

695 Beck, U. 2000. What Is Globalization? Cambridge: Polity Press.

Bell, Q. 1976. On Human Finery. London: Hogarth Press.

Berdichevsky, L., Y. Poria, and N. Uriely. 2013. "Sexual Behavior in Women's Tourist Experiences: Motivations, Behaviors, and Meanings." Tourism Management 35: 144-155. doi:10.1016/j. tourman.2012.06.011.

Berger, P. L., and T. Luckmann. 1967. The Social Construction of Reality: A Treatise in the Sociology of Knowledge. New York: Anchor.

Bourdieu, P. 1977. Outline of a Theory of Practice. Translated by Richard Nice. Cambridge: Cambridge University Press.

Bourdieu, P. 1984. Distinction: A Social Critique of the Judgement of Taste. Translated by Richard Nice. London: Routledge and Kegan Paul.

Bourdieu, P. 1986. "The Forms of Capital." In Handbook of Theory and Research for the Sociology of Education, edited by J. G. Richardson, 241-258. New York: Greenwood Press.

Bourdieu, P. 2000. Pascalian Meditations. Cambridge: Polity Press.

Bourdieu, P., and L. Wacquant. 1992. An Invitation to Reflexive Sociology. Chicago, IL: The University of Chicago Press.

Callon, M. 1999. "Actor-Network Theory - The Market Test." In Actor-Network Theory and After, edited by J. Hassard and J. Law, 181-195. Oxford: Blackwell.

710 Cohen, E. 1973. "Nomads from Affluence: Notes on the Phenomenon of Drifter-tourism." International Journal of Comparative Sociology 14 (1-2): 89-103.

Colchester, C., ed. 2003. Clothing the Pacific. London: Berg.

Corden, A., and R. Sainsbury. 2006. Using Verbatim Quotations in Reporting Qualitative Social Research: The Views of Research Users. York: University of York.

Crossley, N. 2001. The Social Body: Habit, Identity and Desire. London: Sage.

715 Crouch, D. 2005. "Flirting with Space: Tourism Geographies as Sensuous/Expressive Practice." In Seductions of Place, edited by C. Cartier and A. Lew, 23-34. London: Routledge.

Davis, F. 1992. Fashion, Culture and Identity. Chicago, IL: University of Chicago Press.

De Certeau, M. 1988. The Practice of Everyday Life. Berkeley: The University of Berkeley Press.

Edensor, T. 2001. "Performing Tourism, Staging Tourism - (Re)producing Tourist Space and Practice." Tourist Studies 1 (1): 59-81. doi:10.1177/146879760100100104.

Entwistle, J. 2000a. The Fashioned Body: Fashion, Dress, and Modern Social Theory. Malden, MA: Polity Press. 
Entwistle, J. 2000b. "Fashion and the Fleshy Body: Dress as Embodied Practice." Fashion Theory 4 (3): 323-347. doi:10.2752/136270400778995471.

Entwistle, J. 2014. "Fashion \& the Fleshy Body: Dress as Embodied Practice." Vestoj. http://vestoj.com/ fashion-and-the-fleshy-body-on-dress-as-an-embodied-practice/.

Falconer, E. 2013. "Transformation of the Backpacking Food Tourist: Emotions and Conflicts." Tourist Studies 13 (1): 21-35. doi:10.1177/1468797613477769.

Farber, D., and B. L. Bailey. 2001. The Columbia Guide to America in the 1960s. New York: Columbia University Press.

Farrell, J. J. 1997. The Spirit of the Sixties: The Making of Post-war Radicalism. New York: Routledge.

Fillieule, O. 2010. "Some Elements of an Interactionist Approach to Political Disengagement." Social Movement Studies 9 (1): 1-15. doi:10.1080/14742830903442436.

Garfinkel, H., and D. L. Wieder. 1992. "Two Incommensurable, Asymmetrically Alternate Technologies of Social Analysis." In Text in Context: Contributions to Ethnomethodology, edited by G. Watson and S. M. Seiler, 175-206. New York: Sage.

Giddens, A. 1984. The Constitution of Society. Outline of the Theory of Structuration. Cambridge: Polity Press.

Gimlin, D. 2007. "What is 'Body Work'? A Review of the Literature." Sociology Compass 1 (1): 353-370. doi:10.1111/j.1751-9020.2007.00015.x.

Goffman, E. 1971. Relations in Public: Microstudies of the Public Order. New York: Basic Books.

Goodman, N. 1978. The Ways of Worldmaking. Sussex: Harvester.

Guest, G., A. Bunce, and L. Johnson. 2006. "How Many Interviews Are Enough? An Experiment with Data Saturation and Variability." Field Methods 18 (1): 59-82. doi:10.1177/1525822X05279903.

Havitz, M., and F. Dimanche. 1997. "Leisure Involvement Revisited: Conceptual Conundrums and Measurement Advances." Journal of Leisure Research 29 (3): 245-278.

Hottola, P. 2008. "Farewell to Countercultural Wanderer? Dress and Styles in South Asian Backpacking." Tourism, Culture \& Communication 8 (1): 45-52. doi:10.3727/109830408783900343.

Johnson, D. P. 2008. Contemporary Sociological Theory: An Integrated Multi-level Approach. New York: Springer.

Joy, A., J. Sherry, A. Venkatesh, J. Wang, and R. Chan. 2012. "Fast Fashion, Sustainability, and the Ethical Appeal of Luxury Brands." Fashion Theory: The Journal of Dress, Body and Culture 16 (3): 273-296. doi:10.2752/175174112X13340749707123.

Lamont, M., and V. Molnár. 2001. "How Blacks Use Consumption to Shape Their Collective Identity: Evidence from Marketing Specialists." Journal of Consumer Culture 1 (1): 31-45.

Luo, X., S. Huang, and G. Brown. 2015. "Backpacking in China: A Netnographic Analysis of Donkey Friends' Travel Behaviour." Journal of China Tourism Research 11 (1): 67-84. doi:10.1080/ 19388160.2014.908757.

MacLean, R. 2006. Magic Bus: On the Hippie Trail from Istanbul to India. London: Viking.

Mills, R. 1973. Young Outsiders: A Study of Alternative Communities. London: Routledge \& Kegan Paul. Muzaini, H. 2006. "Backpacking Southeast Asia: Strategies of Looking Local." Annals of Tourism Research 33 (1): 144-161. doi:10.1016/j.annals.2005.07.004.

Neville, R. 1970. Play Power. London: Jonathan Cape.

Nikolakakis, M. 2015. "Representations and Social Practices of Alternative Tourists in Post-war Greece to the End of the Greek Military Junta." Journal of Tourism History. doi:10.1080/1755182X.2015. 1062567.

Olson, M. 1965. The Logic of Collective Action: Public Goods and the Theory of Groups. Harvard University Press.

O'Regan, M. 2010. "Backpacker Mobilities: The Practice and Performance of Travellerscapes in a Global World." Unpublished PhD Thesis, University of Brighton, Brighton.

O'Regan, M. 2015. "Methodological Bricolage: A Journey on the Road Less Traveled in Tourism Studies." Tourism Analysis 20 (5): 457-467. doi:10.3727/108354215X14265319207434.

Paris, C. M., M. Ghazali, and T. Thinaranjeney. 2015. "A Comparison Between Asian and Australasia Backpackers Using Cultural Consensus Analysis." Current Issues in Tourism 18 (2): 175-195. doi:10.1080/13683500.2014.920771. 
Pearce, P., and U. L. Lee. 2005. "Developing the Travel Career Approach to Tourist Motivation." Journal of Travel Research 43 (3): 226-237. doi:10.1177/0047287504272020.

Peillon, M. 1998. "Bourdieu's Field and the Sociology of Welfare." Journal of Social Policy 27 (2): $213-$ 229.

Puar, J. 1994. “Writing My Way 'Home': Traveling South Asian Bodies and Diasporic Journeys." Socialist Review 24 (4): 75-108.

Raj, P. A. 1976. Nepal-a Traveller's Guide. Lonely Planet.

Said, E. 2001. Reflections on Exile and Other Essays. 2nd ed. Cambridge: Harvard University Press.

Shaffer, T. S. 2004. "Performing Backpacking: Constructing 'Authenticity' Every Step of the Way." Text \& Performance Quarterly 24 (2): 139-160. doi:10.1080/1046293042000288362.

Sharma, K. K. 2000. Planning for Tourism. New Delhi: Sarup and Sons.

Sørensen, A. 2003. "Backpacker Ethnography." Annals of Tourism Research 30 (4): 847-867. doi:10. 1016/S0160-7383(03)00063-X.

Stebbins, R. A. 1982. "Serious Leisure: A Conceptual Statement." Pacific Sociological Review 25 (2): 251-272. doi:10.2307/1388726.

Stephens, J. 1998. Anti-disciplinary Protest: Sixties Radicalism and Postmodernism. Cambridge: Cambridge University.

Stonza, A. 2001. "Anthropology of Tourism: Forging New Ground for Ecotourism and Other Alternatives." Annual Review of Anthropology 30: 261-283. doi:10.1146/annurev.anthro.30.1.261.

Suri, J. 2009. "The Rise and Fall of an International Counterculture, 1960-1975." The American Historical Review 114 (1): 45-68.

Sweetman, P. 2003. "Twenty-First Century Disease? Habitual Reflexivity or the Reflexive Habitus." The Sociological Review 51 (4): 528-549. doi:10.1111/j.1467-954X.2003.00434.x.

Teas, J. ([1988] 1974). "I'm Studying Monkeys; What Do You Do? - Youth and Travelers in Nepal." In Anthropological Research on Contemporary Tourism: Student Papers from Berkeley, Volume 67/68, edited by M. C. Inhorn, 35-41. Kroeber Anthropological Society Papers.

Teo, P., and S. Leong. 2006. "A Postcolonial Analysis of Backpacking." Annals of Tourism Research 33 (1): 109-131. doi:10.1016/j.annals.2005.05.001.

Tesfahuney, M. 1998. "Mobility, Racism and Geopolitics." Political Geography 17 (5): 499-515. doi:10. 1016/S0962-6298(97)00022-X.

Thornton, S. 1995. Club Cultures: Music, Media and Subcultural Capital. Cambridge: Polity.

Thorpe, H. 2004. "Embodied Boarders: Snowboarding, Status and Style." Waikato Journal of Education 10: $181-201$.

Tomory, D. 1996. A Season in Heaven: True Tales from the Road to Kathmandu. Hawthorn: Lonely Planet Publications.

Turner, L., and J. Ash. 1976. The Golden Hordes: International Tourism and the Pleasure Periphery. New York: St. Martin Press.

Unruh, D. R. 1980. "The Nature of Social Worlds." Pacific Sociological Review 23 (3): 271-296. doi:10. 2307/1388823.

Vogt, J. 1976. "Wandering: Youth and Travel Behaviour." Annals of Tourism Research 4 (1): 25-41.

Wacquant, L. 1998. "Pierre Bourdieu." In Key Contemporary Thinkers, edited by R. Stones, 261-277 and 411-414. London: Macmillan.

Waterson, R. 2005. "Enduring Landscape, Changing Habitus: The Sa'dan Toraja of Sulawesi, Indonesia." In Habitus: A Sense of Place, edited by J. Hillier and E. Rooksby, 317-338. Aldershot: Ashgate.

Welk, P. 2004. "The Beaten Track: Anti-Tourism as an Element of Backpacker Identity Construction." In The Global Nomad - Backpacker Travel in Theory and Practice, edited by G. Richards and J. Wilson, 77-91. Clevedon: Channel View.

Wheeler, T., and M. Wheeler. 2007. Unlikely Destinations: The Lonely Planet Story. Singapore: Periplus. Wilson, E. 1985. Adorned in Dreams: Fashion and Modernity. London: Virago.

Zurick, D. 1995. Errant Journeys: Adventure Travel in a Modern Age. Austin: University of Texas Press. 